\title{
Export dependence and institutional change in wage bargaining in Germany
}

Article

Accepted Version

Raess, D. (2014) Export dependence and institutional change in wage bargaining in Germany. International Studies

Quarterly, 58 (2). pp. 282-294. ISSN 1468-2478 doi:

https://doi.org/10.1111/isqu.12096 Available at

https://centaur.reading.ac.uk/69441/

It is advisable to refer to the publisher's version if you intend to cite from the work. See Guidance on citing.

Published version at: http://onlinelibrary.wiley.com/doi/10.1111/isqu.12096/full

To link to this article DOI: http://dx.doi.org/10.1111/isqu.12096

Publisher: Wiley-Blackwell

All outputs in CentAUR are protected by Intellectual Property Rights law, including copyright law. Copyright and IPR is retained by the creators or other copyright holders. Terms and conditions for use of this material are defined in the End User Agreement.

\section{www.reading.ac.uk/centaur}

\section{CentAUR}

Central Archive at the University of Reading

Reading's research outputs online 


\title{
Export Dependence and Institutional Change in Wage Bargaining in Germany
}

\author{
DAMIAN RAESS \\ Université de Genève
}

This article explores the adjustment of wage bargaining institutions to international trade in Germany. Embracing IPE as opposed to CPE lenses yields a novel interpretation of change in the institution of wage bargaining. Export dependence of a sector, we argue, has destabilizing effects for industry-wide bargaining by sparking an intra-sectoral cleavage between domestic- and export-oriented enterprises. Specifically, the greater the degree of export dependence of a sector, the greater the degree to which domestic-oriented enterprises within that sector will abandon collective bargaining. We also explain how work-place employee representation through works councils mitigates this effect, such that the presence of works councils helps domestically-oriented firms to hold to collective bargaining agreements in the face of a sector's deepening exposure to export markets. These claims find empirical support in the history of labor-relations developments in the metal industry and, especially, in extensive analysis of a cross-section of establishments. Our findings attribute major responsibility to the firms driving globalization for undermining collective bargaining institutions, and suggest that economic globalization is a cause of dualization. In all, the article provides fresh ammunition for a version of globalization-induced institutional conversion.

Keywords: globalization, collective bargaining, domestic-/export-oriented firm cleavage, works councils, dualization, convergence

\section{Author's notes:}

This article has a long history. I thank Klaus Armingeon, Lucio Baccaro, Brian Burgoon, Alex Colvin, Isabelle Ferreras, Richard Freeman, Jean-Christophe Graz, Peter Hall, Thomas Kochan, Jonas Pontusson, Kathleen Thelen, Christine Trampusch, Sigurt Vitols, Stefanie Walter, Christopher Wendt, Daniel Ziblatt and three reviewers for helpful comments and suggestions at different stages of the project. I also thank participants in the 2009 Industry Studies Conference, the 2010 Annual Congress of the Swiss Political Science Association, the MIT Graduate Student Work-in-Progress Group, the Harvard Research Workshop in Political Economy, and the staff seminars at the département de science politique, Université de Genève, and at the Centre de recherche interdisciplinaire sur l'international (CRII), Université de Lausanne. The research was financially supported by the Amsterdam School for Social science Research and the Swiss Nation Science Foundation (grant number PA0011_121485). 
This article explores the impact of Germany's insertion in the international division of labor as a stellar exporter on industry-wide collective bargaining and discusses the implications for labor market dualization and institutional convergence. Comparative political economists have downplayed the effects of economic globalization on bargaining institutions, focusing on domestic factors instead. Papers by Thelen (2000) and Silvia and Schroeder (2007) engage arguments about globalization and institutional change in wage bargaining, yet neither considers export dependence as a determinant of institutional change. And whatever the origins of the erosion of collective bargaining institutions, scholars point to tension within employers' associations in the form of a small/large firm cleavage. A different research tradition argues that openness leads to more social spending (Cameron 1978; Katzenstein 1985; Rodrik 1998). But globalization appears no longer to be associated with the compensation mechanism of welfare states in open economies the way it long was (Busemeyer 2009), suggesting that governments find it increasingly difficult to compensate the losers of globalization. To the extent that collectively-agreed working conditions constitute welfare compensation and encompassing bargaining institutions foster compensatory policies, we have a new effect of globalization in driving labor market dualization by way of how export dependence leads domestic-oriented enterprises to quit employers' associations. Yet the literature on the politics of dualization has neglected the effects of globalization other than immigration (Rueda 2007; King and Rueda 2008; Emmenegger, Häusermann, Palier, and Seeleib-Kaiser 2011).

We focus on change in perhaps the most distinctive institutional pillars of "coordinated" market economies in the flagship country of "organized" capitalism (Hall and Soskice 2001; Höpner 2007). We submit that to understand contemporary adjustments in 
industry-wide wage bargaining requires a systematic analysis of how export dependence impacts wage settlements and collective bargaining coverage, that is, the extent to which firms in a sector adhere to collectively-agreed (wage) norms. Specifically, we argue that the greater the degree of export dependence of a sector, the greater the degree to which domesticoriented enterprises within that sector abandon collective bargaining. The effects of export dependence operate by and large via two channels. First, exporting brings economies of scale and learning effects to those firms that export, enhancing their productivity and profitability. Second, short-term economic gains associated with export upswings in net export-competing sectors tend to push wage settlements up. All in all, export-oriented firms can afford the collectively-agreed wages that take account of a sector's average productivity whereas domestic-oriented firms cannot. But there is a twist, highlighting a locus of political agency in responses to globalization. The effects of a sector's export dependence on the likelihood to follow collective agreements are contingent on workplace institutional condition: the presence of works councils help domestic-oriented enterprises to hold to collective agreements in the face of greater export dependence of a sector, because establishments with works councils respond to trade openness by making more flexibility compromises that allow these firms to reduce costs and remain profitable.

Our study combines in-depth historical analysis of the metalworking sector with large- $\mathrm{N}$ analysis of a cross-section of enterprises in the full gamut of sectors as pertains to the German economy. Export dependence and collective bargaining in metalworking feature central stage in our analysis of institutional change in wage bargaining in Germany because of the sector's pattern-setting function within the system of industrial relations. Over-time analysis of industrial relations developments in metalworking suggests that wage movements 
were responsive to short-term fluctuations in sector's export dependence over the period 1984-2007, and that strong annual export performance adversely affected collective bargaining coverage via higher settlements over the period 1994-2007. And cross-sectional analysis of establishment-level data suggests that higher industry-level export orientation reduces the incidence to follow collective agreements among domestic-oriented firms, but that the presence of works councils tends to mute this effect.

These findings have implications for the politics of institutional change in wage bargaining and for labor market dualization. They point to globalization as a major driving force behind change, though not how previous scholarship has thought. Export dependence of a sector has destabilizing effects for industry-wide bargaining by sparking an intra-sectoral split between domestic-oriented enterprises, on the one hand, and export-oriented firms, on the other, with the divisive pressures running partly via wage bargaining. As export firms fuel a sector's export dependence, globalization does not make of export firms just the "good guys," but the "bad guys." And the differential ability to exploit globalization pits insiders against outsiders, not outsiders at the margins of the system, but those who do not work in firms that enjoy the traction of the German export powerhouse. In short, exposure to export dependence drives dualization, which can also be conceived as a particular form of (rising) inequality.

The analysis also sheds light on the discussion of the role of globalization in leading to institutional convergence among advanced industrial economies. Comparative political economy (CPE) and, especially, the "varieties-of-capitalism" (VofC) approach have been traditionally hostile to the notion of convergence. Within the VofC literature, economic globalization is cast in a light that reinforces existing institutional differences rather than 
leading to institutional convergence. Regarding wage setting, globalization should act as an institutional enforcer as firms compete by using comparative institutional advantage. ${ }^{1}$ Our findings do not necessarily suggest a globalization-driven cross-national convergence in institutional form, but they are consistent with a convergence in institutional functioning along a common neoliberal trajectory of change yielding similar outcomes (Baccaro and Howell 2011). Clearly, industry-wide (and coordinated) bargaining remains a reality in contemporary Germany, but it is less and less encompassing and egalitarian as a result of export dependence. Yet, as we shall see, there is some evidence that under the surface of stability employer coordination is on the wane.

The article is organized in four sections. The first section highlights blind spots in the literature and offers an alternative account of the causal chain linking globalization and institutional change in wage bargaining. The second explores the relationship between export dependence and wage bargaining in the metalworking sector. The third section investigates the effects of export dependence for collective bargaining institutions in metalworking and in a large cross-section of enterprises. A final section concludes.

\section{Related Research and Argument}

Employers' associations are critical organizations in many advanced industrialized economies. They negotiate collective agreements with unions at various levels that address working conditions, including wages and hours. In Germany, collective bargaining occurs mainly at the industry-level and is coordinated across the economy through the wage leadership of the metalworking's union IG Metall. ${ }^{2}$ Industry-level bargaining does not imply 
universal coverage of collective agreements because only firms organized in employers' associations are obliged to provide collectively-agreed standards to employees. ${ }^{3}$ As one of the anchors of coordinated market economies, encompassing bargaining is important because it dovetail with low inequality (Rueda and Pontusson 2000) and with high-wage, high-quality production in international markets (Hall and Soskice 2001). Due to institutional complementarities, the erosion of sectoral bargaining may lead to the demise of organized political economies (Hall and Soskice 2001).

Despite extensive research on centralized systems of collective bargaining, the comparative political economy and globalization literatures provide only limited guidance as to the intricacies of industrial-relations developments in an open economy. Most studies of collective bargaining outcomes (Wallerstein 1990; Hall and Franzese 1998; Mares 2006; Baccaro and Simoni 2010) and institutions (Hassel 1999; Blyth 2001; Kohaut and Schnabel 2003; Culpepper 2008) focus on domestic political-economic, institutional or ideational explanations. Others find that economic globalization does not matter much for wage-setting institutions (Wallerstein 1998; Hassel and Schulten 1998; Streeck 2009). A prominent line of research has suggested how heighted economic competition produced inter-sectoral cleavages among employers about the desirability of nationwide centralization, fuelling downward shifts in the locus of bargaining (Iversen 1996; Swenson and Pontusson 2000). Still others have considered how globalization might hollow out industry-level collective bargaining by spurring an intra-sectoral cleavage among employers, but where the causal mechanisms remain contested and poorly tested across time and space (Thelen and van Wijnbergen 2003; Silvia and Schroeder 2007). 
While focusing similarly on domestic factors, studies of wage bargaining and of bargaining institutions in Germany tend to be compartmentalized or to concentrate on one direction of the interaction - namely how institutions affect wage developments, not the other way around. Scholars have examined the interaction between social policy and the wage strategies of unions, where welfare state expansion was premised on wage restraint (Crouch and Pizzorno 1978), but where welfare state maturation, via changes in the level and composition of welfare commitments, has reduced the incentives for wage moderation (Mares 2006). Along similar lines, research has shown that IG Metall has been willing to forego generous wage increases to finance working time reduction and early retirement (Bispinck 1995; Streeck 2001). Among the scholars exploring the consequences of labor market institutions for economic performance, some have considered how centralization and coordination affect wages (Calmfors and Driffill 1988; Soskice 1990). Also, the independence of the central bank has been instrumental in moderating IG Metall's wage claims (Streeck 1994; Hall and Franzese 1998). Recent research identifies other organizational factors, such as internal governance processes within union confederations involving democratic ratification of collective bargaining contracts, which, in isolation or in combination with coordination, dampen wage growth (Baccaro and Simoni 2010).

Prominent explanations of institutional change in wage bargaining include employer dissatisfaction with the lack of flexibility in one-size-fits-all central agreements (Schroeder and Ruppert 1996:323), ${ }^{4}$ German unification (Silvia 1997; Turner 1998), deindustrialization and the accompanying change in firm size (Hassel 1999), and restructuring via vertical disintegration (Doellgast and Greer 2007). Where globalization is considered as a cause of change, the conclusion is that weaker unions resulting from higher unemployment and 
organizational decline among capital and labor account for pressurized collective bargaining (Hassel and Schulten 1998). Research on large firms has shown that plant-level pacts for employment and competitiveness have been accompanied by greater flexibility of central contracts which helped stabilize the institution of wage bargaining (Rehder 2003; Streeck and Rehder 2003). The latest entry in the debate makes the case for endogeneous, selfundermining change (Streeck 2009). Whatever the cause, the CPE literature is virtually unanimous that a split between small- and medium-sized enterprises, on the one hand, and large firms, on the other, lies behind the erosion of German wage bargaining institutions (Schroeder and Ruppert 1996; Völkl 1998; Thelen 2000; Hassel and Rehder 2001; Zimmer 2002; Streeck 2009).

Two papers addressing globalization and collective bargaining institutions deserve close scrutiny. Thelen (2000; Thelen and van Wijnbergen 2003) is rightly credited for spelling out the feedback effect of wage negotiations for industry-wide bargaining in an open economy. Heightened competition fuels the international diffusion of innovative organizational practices (another "aspect of globalization" in Thelen's terminology) that gives rise to a new production regime characterized by tightly coupled networks of suppliers and assemblers. Interdependence increases employers' vulnerability to industrial stoppages because they fear losing contracts to domestic (that is, located in other bargaining districts) and foreign competitors. Relying on cooperative relations among and within firms for success, employers turn reluctant to use the lockout. Knowing this, the unions demand higher wages. When push comes to shove, large firms prefer to buy labor peace by paying more expensive settlements they can afford due to productivity gains reaped via the introduction of flexible working-time arrangements. Small enterprises cannot afford them because 
workplace flexibility is less practicable in small than in large firms. As employers' associations yield to large firm pressures, small enterprises express discontent by voting with their feet, setting in motion a vicious circle of exits from employers' associations as the defection of small firms unwilling to pay high settlements rises the odds of remaining employers to sign an expansive wage deal in the next round.

Based on analysis of compensation data over four decades, Silvia and Schroeder (2007) show that annual wage changes in metalworking grew smaller over time. Accordingly, they reject Thelen's thesis that organized labor contributed to the cost pressures that led small and medium-sized enterprises to leave the metal employers' associations as the economy grew more interdependent. They argue instead that global price pressures imposed by assemblers on suppliers, followed by the change in firm size toward small enterprises and the poor provision of employer-association services to small firms account for the dwindling membership density of employers' associations. In sum, while acknowledging the small/large firm cleavage, they highlight a new cleavage involving supplier-assembler relations along the production chain. This directly contradicts Thelen and van Wijnbergen (2003:874-75) who expect supplier firms operating in tightly coupled, just-in-time production networks to share assemblers' interest in uninterrupted production and hence to stay in employers' associations. ${ }^{5}$ Although these studies have considerably increased our understanding of changing bargaining institutions under openness, their disagreement over what facet of globalization matters, what cleavage globalization nurtures, and whether the effect of globalization runs via union-led wage bargaining suggests that they have not exhausted the topic. 
This article offers a new interpretation of globalization and industrial-relations developments in Germany, one that takes into account the full power of the German export wonder machine. Empirically, the paper improves on earlier studies by measuring export dependence, collectively-set wage increases and wage bargaining coverage in metalworking over time, ${ }^{6}$ and by exploiting large- $\mathrm{N}$ cross-sectional data comprising a range of enterpriselevel information including size, degree of export orientation, and decision to follow collective bargaining agreements. ${ }^{7}$ Our contribution adopts IPE-lenses to a subject almost exclusively studied within CPE. It is noteworthy that the entries to the debates reviewed above come from comparative politics or country experts who tend to share a neoinstitutionalist approach and write within the VofC approach and its dual convergence thesis. Where cross-fertilization occurred, the treatment of globalization is most often unsatisfactory. For example, the global price pressures in Silvia and Schroeder's (2007) account are loosely defined, preventing us from disentangling the different sources of global competitive pressures. Hay (2004:247-48) perceptively noted the VofC's inadequate handling of globalization as a causal process, concluding that "[ $t]$ his surely suggests the need to examine the inputs side of the equation in a rather more detailed and empirically exhaustive fashion." This article provides just that.

Regarding wage developments under collective bargaining in the export-oriented German economy, we consider wage bargaining involving a net export-competing sector (that is, exports minus imports as a share of sector production $>0$ ). The specific-factors model of international trade predicts workers in sectors that make intensive use of the abundant (scarce) factor to benefit (lose) from trade in the short run, net of individual's skill level (Alt, Frieden, Gilligan, Rodrik, and Rogowski 1996). The welfare of employed workers is tied to 
the overall fortunes of the sector in which they are employed, with capital and labor gaining (losing) from trade liberalization in a net export-competing (import-competing) sector (Davidson and Matusz 2004:10). A sector's net exports (imports) captures the implications of trade for particular producer-groups where inter-sectoral factor mobility is limited, and taps partly into revealed comparative advantage (comparative disadvantage)(Gilligan 1997; Hiscox 1999; Mayda and Rodrik 2005). Accordingly, we expect different politics surrounding collective wage bargaining in net export- and import-competing sectors, with trade unions likely to pursue a more militant wage strategy in the former than in the latter. This logic should extend to short-term changes in the level of a sector's net exportcompetition because of short-term economic gains and losses associated with the strengthening and the weakening of the sector's comparative advantage position, respectively. Specifically, in net exporting-competing sectors such as metalworking, we expect short-term economic gains associated with upswings in export markets to benefit the wage position of workers via higher wage settlements, but we expect short-term downswings in export success to contain the negotiated wage increment (Hypothesis 1).

Regarding institutional change in wage bargaining in an open economy, we consider the effects of export orientation on enterprise's decision to follow collective agreements. These effects operate mainly via two mechanisms. First, exporting brings economies of scale and learning effects, enhancing firm productivity and profitability (Frieden and Rogowski 1996:39; Bernard and Wagner 1997; Wagner 2007). ${ }^{8}$ Exporting enlarges the available market by opening up sales opportunities abroad. As exporting firms produce more of a same good, manufacturing costs per unit decrease due to economies of scale. The larger the scale of output associated with the enlarged market, the larger the economic benefits accruing to 
exporting firms (Milner 1997; Chase 2003). Exporting also provides expert information from international customers and suppliers about a wide variety of factors such as market conditions, technological and process improvements that improve the post-entry performance of export starters (Frieden and Rogowski 1996:39). The knowledge and networks so built ought to be cumulative, implying productivity gaps not only between exporters and nonexporters, but also between firms more or less exposed to export markets (Wagner 2007). Further, firms participating in foreign markets are exposed to fiercer competition and accordingly need to improve faster than firms who sell their goods domestically only. Facing competition abroad creates incentives for technological progress, management efficiency and greater capacity utilization, all of which contribute to output and productivity growth (Bernard and Wagner 1997:135). In short, as export markets enhance the role of scale economies in production and generate learning effects, we expect divisions within sectors among domestic- and export-oriented firms to grow.

The second mechanism relates to the regime shift in collective bargaining toward the economic performance of that part of the sector that is export-oriented (H1). By seeking to capture their legitimate share of rents associated with expanding exports in net exportoriented sectors, the unions target economic conditions in the profitable exporting firms, which in turn is detrimental to the domestic-oriented firms' ability to pay the collectivelyagreed wage rates. Whereas export-oriented firms can afford the collectively-set wages that take into account average sector productivity, domestic-oriented firms cannot because average sector productivity factors in productivity gains associated with export success. Due to bargaining coordination via the pace-setting function of the metal sector, such regime shift should spill over not only to other net export-competing sectors, but also at least partially to 
net import-competing sectors. The divisive pressures in a sector should be stronger in sectors with high levels of exposure to exports, reflecting an accumulation of strong annual export performance over time that unions do not fail to exploit. In short, higher export orientation of a sector should decrease the likelihood to follow collective bargaining agreements among domestic-oriented enterprises in that sector (Hypothesis 2). ${ }^{9}$

The intuition motivating our expectation that workplace institutional condition mediates how globalization affects enterprise-level decision to sign on to collective agreements originates in scholarship on how globalization affects national polities which acknowledges that national institutions mediate globalization's effects (Garrett 1998; Swank 2002). Works councils provide establishment-level employee representation in many EU countries where they are protected by law. In Germany, they are authorized (but not automatic) in establishments with five permanent employees, hence they may exist regardless of whether a firm is covered by a collective agreement. They negotiate over issues that fall under co-determination rights, including the organization of work, working-time arrangements, and atypical contracts. They are formally independent from but often have close ties with unions, as the latter have historically mobilized rank-and-file members to run in works council elections with considerable success (Hassel 1999).

Works councils may condition how globalization affects collective bargaining coverage for two reasons. First, workplace employee representation bodies aggregate the interests of employees and increase their capacities in negotiations relative to employers. This suggests that enterprises with works councils should have conditions more favorable to employees' interests than enterprises without such worker organization. This is consistent with empirical evidence showing how employees represented by works councils fare better 
than their unrepresented counterparts in terms of wages and collective bargaining coverage (Kohaut and Schnabel 2003; Addison, Teixeira, and Zwick 2010).

Second, in the context of intensified global competition, works councils might engage in strategic behavior that trades off employment issues with high employee priorities against issues with low employee priorities. Employees are more divided about the benefits of flexibility than of job security. Against the backdrop of increased international competition and more opportunities for plant-level deviations from sectoral collective agreement standards since the early 1990s, works councils have engaged in concessions involving flexible working-time arrangements, atypical employment contracts, and variable pay in exchange for investment and/or employment guarantees (Hassel and Rehder 2001; Kurdelbusch 2002; Rehder 2003; Raess and Burgoon 2006). Recent research details such quid pro quo agreements across work-time issues, where enterprises with works councils facing increased trade and international investment trade off greater employment flexibility, such as temporary or fixed-term contracts and "balancing time accounts," against the protection of employees' standard weekly hours (Burgoon and Raess 2009). Such strategic bargaining might well extend to the wage position of workers and to collective agreements that protect wages and standard hours, given how wages and hours, just like job security, are more central to employee preferences than is flexibility. Inasmuch the effects of export dependence of a sector fall on domestic-oriented enterprises (H2), we expect the presence of works councils among those firms to moderate globalization's tendency to decrease the odds of following collective agreements, because flexibility compromises allows them to reduce costs and remain profitable. In short, higher sector-level export orientation should less 
substantially decrease domestic-oriented establishments' likelihood to follow collective agreements when they have a works council than when they do not (Hypothesis 3).

There is one caveat. The years in question were a time of production relocation. Globalization in the form of plant relocation resulted in some hollowing out of German production as well as declining overall costs due to stages of the production process being outsourced to Eastern Europe. Assuming that the proceeds from relocation are shared with the remaining workforce, we would expect a cleavage between firms engaged in international outsourcing and those that aren't. Unfortunately, our data does not allow us to test such a hypothesis. ${ }^{10}$ However, we know that small firms were less able to make use of relocation than large ones (DIHT 1993; DIHK 2003). And to the extent that outward FDI in a sector serves as a proxy for the degree of relocation, our quantitative analysis gets at this alternative explanation, imperfectly, by controlling for organization size and outward FDI.

\section{Export Dependence and Wage Bargaining in Metalworking}

This section considers the globalization-wage bargaining nexus in metalworking, presumably an important intervening link to understand adjustments of industry-wide bargaining institutions to trade. Streeck (1994:126) has long surmised "just as the Bundesbank's non-negotiable tight monetary policy, the international exposure of its industries forces IG Metall to moderate its wage demands." Is such claim, reminiscent of broader neocorporatist arguments, born out in the data?

\subsection{Trends in Wage Settlements (1971-2007)}


To assess the union's contribution to costs via its wage bargaining strategy, we collected annual data on the wage increase agreed upon by IG Metall and Gesamtmetall in their (bi-) annual bargaining rounds from the early 1970s to the late 2000s. ${ }^{11}$ Using statistics on annual change in consumer prices, we compiled a measure of annual real wage increase. The pattern-setting function of the metalworking sector forces IG Metall to consider productivity growth for the economy as a whole (that is, total productivity) as a key parameter in its bargaining strategy (Streeck 1994). Figure 1 illustrates ten-year average increases in real wage and total productivity over the period $1971-2007 .^{12}$

\section{[Figure 1 Here]}

Costs owing to collective wage bargaining grew larger over time. Taking into account that productivity in the 1990s is inflated due to the surge in Eastern German productivity after reunification, Figure 1 shows that the extent of wage moderation decreased in each successive decade since the 1970s (shown by the narrowing gap between the two lines as time passes). Assessing IG Metall's wage strategy against its own goal yields a similar result: the incidence of redistributive bargaining (that is, nominal wage increment greater than the sum of inflation and productivity) grew over time with an inflection in the 1990s. Figure 1 also shows that wage settlements remained below changes in total productivity (and far below productivity increases in metal) throughout the period —an indication of wage moderation.

In short, whereas wage moderation characterizes the entire period 1971-2007, the extent of wage moderation declined over time. ${ }^{13}$ In a sense, IG Metall resisted employers' calls to reduce wage costs better than expected as the sector grew more integrated into world markets. Our data hence lend support to Thelen's thesis that wage costs have grown bigger in recent years as a consequence of wage bargaining. This is not to say that there has been a 
linear trend of rising annual wage settlements. Fine-grained analysis reveals significant variation over time, such as low real wage increases in the early 1980s and 1990s, relatively high increments in the late 1980s and 1990s, but moderate hikes in 1997-1998 and 20002001. The next section seeks to explain this sort of variation.

\subsection{Wage Determination under Collective Bargaining in an Open Economy}

Does globalization account for the movements in wage settlements in metalworking over the past decades? Using exports and production statistics from the Federal Statistical Office, we compiled a measure of annual change in export dependence (that is, exports in the sector as a share of sector production) from 1981 onward. ${ }^{14}$ This globalization measure is lagged two years due to context-specific reasons (see below) to take account of delays in negotiated responses to economic conditions.

Correlation analysis provides a first impression of the pattern in the data. Figure 2 shows the co-variation between lagged change in export dependence and real wage increase over the period 1984-2007. The two lines clearly move in tandem. The strength of the correlation is .61. The relationship is even stronger (.74) over the period 1994-2007 when economic globalization was arguably salient (for example, the "Standort-Deutschland" debate). ${ }^{15}$ These positive correlations are consistent with Hypothesis 1.

\section{[Figure 2 Here]}

We next turn to multivariate analysis of the determinants of wage settlements. ${ }^{16}$ The annual rate of real wage change is a continuous variable for which the estimator is OLS. Table 1 reports results for a range of percentage change regression models with change in export dependence as regressor. For the period 1984-2007, bivariate regression yields a 
positive and statistically significant coefficient (column 1). Export dependence remains positive and significant in our baseline model that controls for change in total productivity and unemployment (column 2). This model performs well, accounting for 56 percent of the variance in wage increments. The full model, including economic growth and annual change in employment as additional controls, performs similarly (column 3). Finally, to test for time dependency, we re-estimate the baseline model by adding the lagged dependent variable on the right-hand-side (column 4). Whereas the controls perform in line with expectations, change in exports positively and significantly predicts wage increases. The size of the effect is fairly strong: moving from 0 to 4.6 percent of export growth (from the $25^{\text {th }}$ to the $75^{\text {th }}$ percentile) yields an annual real wage increase of 1.1 percent. The same models display even stronger results over the period 1994-2007. In sum, consistent with Hypothesis 1, wage bargaining in metal has been responsive to lagged change in export performance in the last quarter of a century.

\section{[Table 1 Here]}

The results are robust to a range of alternate estimations, including changing the control variables (for example, productivity in metal, unemployment levels), the time lags in the controls, and estimating nominal wage increases with annual change in consumer prices on the right-hand-side. However, the results are sensitive to a change in the lag of the independent variable. Taking an average of two- and one-year lags in exports change, we obtain a positive coefficient that borders significance level for most estimations. But the association does not hold when export dependence is lagged one-year. This is not surprising because the annual change in export share, unlike the annual level in sector's export share, 
varies greatly from year to year (Figure 2). It is therefore critical to identify the right time lag.

In-depth knowledge of labor relations in the metal industry gained from extensive fieldwork and analysis of the organizational set-up of wage campaigns reveal that a two-year lag in the globalization variable is appropriate. Collective agreements are typically concluded in the first half of a given yeart (IG Metall 2002). Although the metalworking union's internal decision-making regarding wage claims is skewed toward the central board, bargaining commissions at the district level coordinate consultations among union members and shop stewards that inform central deliberations (Weiss and Schmidt 2000:150; IG Metall 2002). These consultations and the formulation of the initial wage claim occur in the year preceding the settlement (t-1). Documentary evidence shows that lagged export performance is a parameter on the mind of union leaders when debating the wage claim (at t-1): IG Metall's internal position papers graphically depict and discuss trends in exports lagged one yearhence lagged two years in relation to the wage settlement-alongside productivity, consumer prices, employment and economic growth (for example, IG Metall 2001). This suggests that lagged (t-2) export performance informs the union's wage demands and likely affects the settlement level. ${ }^{17}$

Further examination of the union's decision-making process regarding wage claims adds credence to Hypothesis 1. As mentioned, bargaining commissions in each district coordinate extensive consultations. Works councils' representatives from large, exporting firms dominate these commissions (Hassel and Kittel 2001:14; Carlin and Soskice 2009:72). Therefore, the wage increment is likely to be strongly influenced by economic conditions in those firms. 
In short, although IG Metall wage bargaining has been responsive to changes in the sector's export performance since 1984, steady export growth helped spur higher real wage increases on a yearly basis since 1994 (Figure 2). This provides a different construal of the "big victories" by organized labor than the one proposed by Thelen: the union merely captures its fair share of increased rents stemming from short-term gains of the sector's expansion through exports. Accordingly, the two-year contract that sealed the real wage increases of 1.6 percent in 1995 and 2.2 percent in 1996-the empirical centerpiece of Thelen's analysis — was neither excessive nor generous, but enabled by strong export growth in the preceding years (2.1 percent in 1993, 6.3 percent in 1994). This and other recent settlements thus appear to be instances where the union made legitimate and affordable wage claims in relation to employers in the export-oriented part of the sector.

\section{Export Dependence and Institutional Change in Wage Bargaining}

The erosion of collective bargaining coverage is well documented. The decline in the metalworking employers' association density has been staggering: the density of Western German employers' associations in terms of employment fell from 75 to 55 percent between 1977 and 2007. ${ }^{18}$ For West Germany as a whole, industry-level collective bargaining coverage decreased from 72 percent of employees to 63 between 1995 and 2001 (Kohaut and Schnabel 2003:199). We focus on West Germany because the decline in employers' association membership has been much steeper and industrial relations developments different in the East (Schroeder 2000). Rising globalization has coincided with declining coverage, but has the former caused the latter? 


\subsection{Evidence from Metalworking}

We explore whether change in sector's export performance affects aggregate collective bargaining coverage and whether such effect runs via wage bargaining. This requires an empirical analysis in two steps. First, we estimate the total effect of globalization measure on collective agreement coverage. Second, we re-estimate the same relationship this time controlling for annual wage changes, which gives the direct effect of globalization on coverage. Lacking a reliable measure of the density of metalworking employers' associations in terms of companies (theoretically our preferred measure), we use data on employment density instead. Given the less-than-ideal quality of this measure, we must be cautious about drawing any strong conclusions from this analysis. ${ }^{19}$

Table 2 summarizes the main results for 1994-2007. Column 1 shows a negative and significant effect of change in exports on collective bargaining coverage, suggesting that an increase in exports reduces aggregate coverage. When we control for the annual change in wage (column 2), the globalization term, which shows the direct effect of change in export dependence on change in coverage, loses statistical significance. This implies that the effect of exports on collective agreement coverage works through the indirect effect exports have on the wage settlements. Columns 3-4 show that this pattern does not reflect serial correlation. Although firm-level data is required to find out what kind of companies left employers' association, the finding that linkage between sectoral exports and wage bargaining has reduced aggregate coverage in recent years is consistent with the fact that the pressure to hold to collective agreement has fallen disproportionately on non-exporting firms, lending plausibility to Hypothesis 2 .

\section{[Table 2 Here]}


Streeck (2009:187) claims that the intensification of globalization in the 1980s and 1990s represents nothing fundamentally new in the German political economy. Our account suggests otherwise. Export dependence in metalworking plateaued at 50 percent in 19811993 but increased from 52 to 79 percent between 1994 and 2006. ${ }^{20}$ The decline in West German collective bargaining coverage kicked in around the mid-1980s, but it did not start in earnest before 1992 or 1995 (Silvia and Schroeder 2007: Figure 1). Our analysis suggests that the linkage between exports and wage bargaining helped nurture tension within the system starting in the mid-1980s, and that the full-blown effect on institutional change began around 1994. In short, the complications booming exports since 1994 generated for the stability of industry-wide bargaining has been different in the 1990s-2000s compared to earlier periods. ${ }^{21}$

\subsection{Evidence from Establishment Survey}

We test our expectations about the effect of export dependence on enterprise-level decision to follow collective agreements using from the IAB Establishment Panel. ${ }^{22}$ The data consists of a representative sample of public and private establishments in Germany, capturing the full range of international exposure in an advanced economy. We focus on a 2002 cross-section of 15,863 establishments, providing a broad cross-section of establishments and variables relevant to our argument (Städele and Müller 2006).

The IAB survey asks about whether establishments follow an industry- or firm-level collective agreement. Our measure is a binary variable, as follows: $0=$ the establishment does not follow collective agreements (no industry-level agreement, no company-level agreement); $1=$ the establishment does follow an industry- or company-level collective 
agreement. Following collective agreements is a stringent measure of collective bargaining coverage, involving the negotiation of a collective contract with the union. It varies within and across industries. This shows up in the data, where 62 percent of respondent enterprises follow collective agreements. The industry with the lowest average is "Legal-accountingadvertising services" (0.12) and the highest "Public administration" (0.97).

We generate a measure of industry-level export dependence from OECD data which is matched to the respondent's two-digit sector of employment, using the NACE industry classification in the IAB Establishment Panel. ${ }^{23}$ The measure is Export share, exports as a share of sector production. The sample mean is .13 , ranging from 0 ("Education") to 1.17 ("Manufacture of office machinery and computers"). Export share is lagged one year to take into account delays in responses to economic conditions.

We use foreign sales, the only direct information on international pressure found in the IAB-data set, to distinguish between domestic- and export-oriented establishments. Foreign sales is defined as exports as a percentage of total sales at the establishment level. The sample mean for foreign sales is 8.05 , ranging from 0 (for example, enterprises in legal and accounting) to 100 (enterprises in electronics). We consider the effects of industry-level export dependence, splitting the sample between domestic- and export-oriented enterprises. Our yardstick for gauging a firm's export-orientation is 10 percent of foreign sales. Previous research has shown that a large swath of establishments in exporting sectors do either not export or have low export intensities (Melitz 2003). ${ }^{24}$

Works council is a binary variable, one if the enterprise has a works/staff council and zero otherwise. We restrict the sample to firms with five or more employees because German labor law stipulates that works councils are authorized in establishments with five or more 
employees, hence probing potential differentiated effects of the workforce's choice for or against the set-up of a works council under globalization. In the 2002 cross-section, the percentage of enterprises with a works council is 46 percent.

Our analysis captures the large/small firm cleavage by controlling for establishment size (measured as total employees). The large/small distinction imperfectly gets at other variables and dynamics, including workplace flexibility that is more practicable in large than in small firms, technological intensity and economies of scale that reduce unit costs in large plants, production relocation that is more extensively used by large firms, and price pressure pushed down the production chain by large assemblers onto small suppliers. To further capture the different ability to alleviate costs via production relocation among firms, we externally code a measure of industry-level outward FDI. ${ }^{25}$ To the extent that trade and FDI are complementary, we expect FDI to more positively (or less negatively) affect the odds to follow collective agreements of exporting than of domestic-oriented enterprises.

Eastern German location should mean fewer collective agreements given the history of industrial relations and lower productivity in the East. Skill level measured as the proportion of unskilled workers should yield lower incidence of following collective agreements, whereas the share of (skilled and unskilled) production workers might under modern (just-in-time) production mean increased likelihood of collective agreements. Unemployment should be associated with fewer collective agreements. ${ }^{26}$ Singleestablishment firms ( 1 if single, 0 if subsidiary or headquarters) ought to negatively relate to collective agreement, reflecting how single enterprises tend to be small, less profitable, family businesses. New plants ( 1 if founded since 1990, 0 if older) might be less likely to follow collective agreements because they may sweat workers to compensate for 
disadvantages vis-à-vis learning effects and market visibility. Public ownership (1 if public, 0 if private) should be positively associated with collective agreements, even though differences between public and private sector labor relations have recently decreased. Others factors such standard weekly hours, working-time and contract flexibility, productivity, and technology might plausibly matter as controls but are excluded from the reported results because they are also likely affected by rather than affecting globalization. We consider such factors in robustness checks.

The estimator for the binary variable following collective agreement is probit. Given possible unit-level heteroskedasticity and correlation, we estimate standard errors with the Huber-White robust-cluster "sandwich" estimator, clustered over the forty-one branches. The models consider separately the main and the mediated effects of how export share affects establishment-level decision to follow collective agreements, splitting the data into domesticand export-oriented firms. All estimations include ten broad sector dummies, to account for unobserved effects of sectors and to address unit-level heteroskedasticity. ${ }^{27}$

Table 3 shows the results for the effects of industry-level export share on the incidence to follow collective agreements among domestic-oriented and exporting establishments, unmediated and mediated by works councils. All controls perform in line with expectations and tend to be statistically significant. Most importantly, enterprises with works councils are more likely to follow collective agreements, and so are large firms, in line with the large/small firm cleavage. Interestingly, outward FDI helps to drive a wedge between domestic- and export-oriented firms, given how it more positively and significantly affects the latter. In short, it appears that exporting firms also benefit from relocating production abroad.

[Table 3 Here] 
Turning to the direct effects of export dependence, industry-level export share is negative and statistically significant among domestic-oriented firms (model 1), suggesting that higher industry-level export dependence decreases the incidence of collective bargaining coverage among domestic-oriented enterprises. Export share is weakly negative but statistically insignificant among exporting firms (model 2), implying no direct effect of export share on the likelihood to follow collective agreements among exporting firms. These results should be interpreted as follows: domestic-oriented enterprises suffer the negative consequences of global trade integration that export-oriented firms fuel, such that the latter, as the agents of globalization, can be said to indirectly hollow out traditional bargaining institutions. We have, thus, evidence of a domestic-/export-oriented firm cleavage and support for Hypothesis 2.

To assess the size of the direct effect requires post-estimation interpretation. We calculate the effect of a change in export share on the predicted probability that a domesticoriented firm follows collective agreements based on model 1, using Stata's prvalue program and setting the remaining variables to their sample means (Long and Freeze 2005). Moving from the $50^{\text {th }}$ through the $90^{\text {th }}$ percentile in the sample distribution of industry-level export dependence (from .004 to .388 of export share) yields a decrease from .59 to .51 in the probability to follow collective agreements among domestic-oriented establishments.

Turning to the effects of export dependence conditional on works councils, higher export share reduces the incidence of following collective agreements among domesticoriented establishments without works councils, shown by the negative and statistically significant globalization coefficient in model 3. And moving from having no works council to having one moderates the extent to which export share diminishes the incidence of 
collective agreements among domestic-oriented enterprises, as seen by the positive and significant interaction term. In sum, the presence of works councils mutes how industry-level export dependence negatively affects collective bargaining coverage among domesticoriented enterprises, in line with Hypothesis $3 .^{28}$

The mediating effect is substantially important. Without works councils, moving from the sample's $50^{\text {th }}$ through the $90^{\text {th }}$ percentile in export dependence (from .004 to .388 of export share), the model predicts a decrease from .50 to .39 in the probability of following collective agreements among domestic-oriented enterprises. With works councils, the same increase in export share reduces that probability from .79 to .76 . Workplace representation helps domestic firms to hold to collective contracts in the face rising exports, albeit without fully redressing the negative effect of globalization.

The results stand up to robustness and sensitivity tests. They are robust to alternate measure of the dependent variable, where 1 is given to firms that follow industry-level agreements only. They stand up to alternate thresholds delineating exporting from nonexporting enterprises, including one-fifth and one-third of foreign sales. Restricting the sample to tradable sectors yields even stronger results in terms of the size of the key coefficients of interest. Including firms with fewer than five employees in the sample leaves the main results intact. Step-wise inclusion and exclusion of various controls does not affect the results either. For instance, they are similar with inclusion of conditions that we see as intervening rather than omitted variables, such as productivity, technology (1 if state-of-theart, 0 otherwise), standard weekly hours, and flexibility (for example, incidence of workingtime accounts and/or fixed-term contracts). Finally, alternative estimators and calculations of standard errors do not affect the results. 


\section{Conclusion}

We have reported empirical analyses on institutional change in wage bargaining related to export orientation in Germany. Based on establishment-level data for a broad range of industries and services, we find export dependence of a sector to reduce incidence of following collective agreements among domestic-oriented enterprises within that sector but to have no effect on exporting firms. We also find that the presence of works councils partly redresses the negative effects of globalization on the likelihood of domestic-oriented enterprises to hold to collective agreements. When confining our analysis to the pacesetting metalworking sector, we find collective wage bargaining to be an intervening link between export dependence and institutional change in wage bargaining: while wage settlements responded to short-term fluctuations in sector's export dependence over the period 19842007, protracted export growth adversely affected collective bargaining coverage via higher wages over the period 1994-2007.

We do not wish to overstate the extent to which our argument differs from the CPE literature's variables, but the differences are real and important. Our analysis documents a new cleavage between domestic-oriented enterprises and export-oriented firms, in addition to the conventional small/large firm cleavage. It helps to clarify competing claims about wage developments under openness. Our data on real wage increases in metalworking over four decades yields some support for Thelen's thesis that wage costs as a result of collective wage bargaining have grown bigger in recent years. That is, while wage moderation has been a constant throughout the period 1971-2007, the extent of wage moderation has decreased in time. But in contrast to Thelen, who stresses employers' loss of the lockout resulting from 
enhanced interdependence in production and fears of losing market share in case of protracted industrial disruption, our explanation of the moderate wage push is rooted in the metal industry's strong export performance. Related to this is a different account of why some firms can afford high wage settlements and others cannot: whereas Thelen focuses on the differential ability to exploit domestic processes such as the introduction of flexible workingtime arrangements, we stress the differential ability to reap productivity gains associated with exporting and export growth.

Our findings clarify contemporary adjustments of collective bargaining institutions, contributing to our understanding of where the unsettling of organized capitalism and labor market dualization come from. First, domestic-oriented enterprises have faced the negative consequences of increased global integration that export-oriented firms have helped to fuel, such that our account focusing on economic globalization does attribute major responsibility to the main agents of globalization in hollowing out traditional institutions. Clearly, exportoriented firms are the "bad guys," not just the "good guys" involved in a cross-class coalition in support of industry-wide bargaining. Second, the new cleavage is as a form of insiders/outsiders divide, pitting those who do not work in firms that harness the full power of economic globalization (and of export growth in particular) against those who do. This suggests that economic globalization is a driver of dualization.

Our findings also suggest ammunition for globalization-induced convergence, not in the sense of institutional identity but of a common neoliberal directionality of change with respect to the functioning of institutions. Yet employer coordination appears not to get out of the process completely unscathed. The VofC argument about why German employers prefer coordination is premised on it being able to sustain export performance in manufacturing. 
Tangible benefits of coordination include amongst other wage moderation and social peace. Regarding the latter, there are two dimensions (Thelen 2000): centralization, by upholding the dual system (that is, unions outside, works councils inside the plant) ensures plant-level cooperation; and coordination entails a uniform timetable for negotiations across firms thereby protecting individual firms from disruptive, isolated wage disputes. Regarding this second dimension, in light of recent evidence showing that as a result of globalization supplier firms are not immune from deserting employers' associations (Raess 2006; Silvia and Schroeder 2007), exporting firms are no longer protected by a same peace obligation involving them and their supplier in the value chain. ${ }^{29}$ This counts as decreasing employer capacity to coordinate. It implies diminishing returns to collective bargaining institutions for exporting firms, possibly representing the seeds of their future demise and of convergence in institutional form.

Recent CPE scholarship explains conflicts over industrial relations, social policy and systems of education and training by stressing difference in preferences between small and large employers (Martin 2000; Mares 2003; Culpepper 2007). As economies continue to grow more interdependent, the cleavages between domestic- and export-oriented firms and sectors are among those differences that shape the destinies of socio-economic institutions under capitalism, the recognition of which has the potential to provide further original interpretations of past and present battles over policy and institutions. More generally, CPE should integrate IPE perspectives more systematically, not just with respect to globalization but also to other processes of interdependence such as international policy coordination or diffusion (for example, Traxler and Brandl 2009; Gilardi 2010). In any event, to consider national models as choices shaped by domestic institutions and actors, as do contemporary 
theories in CPE and the VofC approach in particular, is no longer tenable. Long live the second image reversed (Gourevitch 1978)!

References

Addison, John T., PAulino TeiXeIRA, And Thomas Zwick. (2010) German Works Councils and the Anatomy of Wages. Industrial and Labor Relations Review 63 (2): 247-270. 
Alt, James E., JeFFry Frieden, Michael J. Gilligan, DAni Rodrik, AND RonAlD RogowsKI. (1996) The Political Economy of International Trade. Comparative Political Studies 29 (6): 689-717.

BACCARO, LuCIO, AND MARCo SIMONI. (2010) Organizational Determinants of Wage Moderation. World Politics 62 (4): 594-635.

BACCARO, Lucio, AND Chris Howell. (2011) A Common Neoliberal Trajectory: The Transformation of Industrial Relations in Advanced Capitalism. Politics \& Society 39 (4): 521-563.

Behrens, Martin, And WAdE JACOBy. (2004) The Rise of Experimentalism in German Collective Bargaining. British Journal of Industrial Relations 42 (1): 95-123.

Bernard, ANDrew B., AND JoAChIM WAgner. (1997) Exports and Success in German Manufacturing. Weltwirtschaftlisches Archiv/Review of World Economics 133 (1): 134-157.

BISPINCK, REINHARD. (1995) Tarifpolitik in der ersten Hälfte der 90er Jahre. In Tarifpolitik der Zukunft: Was wird aus dem Flächentarifvertrag, edited by Reinhard Bispinck. Hamburg: VSA-Verlag.

BLyTh, MARK. (2001) The Transformation of the Swedish Model: Economic Ideas ,

Distributional Conflict, and Institutional Change. World Politics 54 (1): 1-26.

BurgoOn, BriAn, AND DAMIAN RAESS. (2009) Globalization and Working Time: Working Hours and Flexibility in Germany. Politics \& Society 37 (4): 554-575.

Busemeyer, Marius R. (2009) From Myth to Reality: Globalization and Public Spending in OECD Countries Revisited. European Journal of Political Research 48: 455-482.

CALMFORS, LARS, AND JOHN DRIFFILl. (1988) Bargaining Structure, Corporatism, and Macroeconomic Performance. Economic Policy 3 (6): 13-61.

CAmeron, David. (1978) The Expansion of the Public Economy: A Comparative Analysis. American Political Science Review 72 (4): 1243-1261.

CARlin, Wendy, AND DAvid Soskice. (2009) German Economic Performance: Disentangling the Role of Supply-side Reforms, Macroeconomic Policy and Coordinated Economy Institutions. Socio-Economc Review 7 (1): 67-99.

ChASE, KERRY A. (2003) Economic Interests and Regional Trade Agreements: The Case of NAFTA. International Organization 57 (1): 137-174. 
Crouch, Colin, And Alessandro Pizzorno, Eds. (1978) The Resurgence of Class

Conflict in Western Europe since 1968. London: Macmillan.

CulPePPER, PEPPER D. (2007) Small States and Skill Specificity: Austria, Switzerland, and Interemployer Cleavages in Coordinated Capitalism. Comparative Political Studies 40 (6): 611-637.

CUlPEPPER, PePPER D. (2008) The Politics of Common Knowledge: Ideas and Institutional Change in Wage Bargaining. International Organization 62 (1): 1-33.

DAVIDSON, CARL, AND STEVEN J. MATUSZ. (2004) International Trade and Labor Markets:

Theory, Evidence, and Policy Implications. Kalamazoo, MI: W.E. Upjohn

Institute for Employment Research.

DIHK. (2003) Produktionsverlagerung als Element der Globalisierungsstrategie von Unternehmen: Ergebnisse einer Unternehmensbefragung. Bonn: Deutsche Industrie-und Handelskammertag.

DIHT. (1993) Produktionsverlagerung ins Ausland: Ergebnisse einer

Unternehmensbefragung. Bonn: Deutscher Industrie-und Handelstag.

DOELlGAST, ViRginia, AND IAN GREER. (2007) Vertical Disintegration and the

Disorganization of German Industrial Relations. British Journal of Industrial Relations 45 (1): 55-76.

EMmenegger, PAtrick, Silja HÄUsermann, Bruno PALIER, AND MARtin SEeleib-

KAISER, Eds. (2011) The Age of Dualization. The Changing Face of Inequality in

Deindustrializing Societies. Oxford: Oxford University Press.

Frieden, JEFFry A., AND RonALD RogOwsKI. (1996) The Impact of the International

Economy on National Policies: An Analytical Overview. In Internationalization and

Domestic Politics, edited by Robert O. Keohane and Helen Milner. Cambridge:

Cambridge University Press.

Garrett, Goeffrey. (1998) Partisan Politics in the Global Economy. Cambridge:

Cambridge University Press.

GILARDI, FABRIZIO. (2010) Who Learns from What in Policy Diffusion Processes?

American Journal of Political Science 54 (3): 650-666.

GoureVitch, PETER. (1978) The Second Image Reversed: The International Sources of Domestic Politics. International Organization 32 (4): 881-912. 
Gilligan, Michael J. (1997) Empowering Exporters: Reciprocity, Delegation, and Collective Action in American Trade Policy. Ann Arbor: University of Michigan Press.

Hall, Peter A., And Robert J. Franzese. (1998) Mixed Signals: Central Bank Independence, Coordinated Wag Bargaining, and European Monetary Union. International Organization 52 (3): 505-535.

Hall, Peter A., AND DAVID Soskice, Eds. (2001). Varieties of Capitalism: The Institutional Foundations of Comparative Advantage. Oxford: Oxford University Press.

HASSEL, ANKE. (1999) The Erosion of the German System of Industrial Relations. British Journal of Industrial Relations 37 (3): 483-505.

HASSEl, ANKE, AND ThORSTEN SCHUlTEN. (1998) Globalization and the Future of Central Collective Bargaining: The Example of the German Metal Industry. Economy and Society 27 (4): 486-522.

HASSEL, ANKE, AND BERNHARD KITTEL. (2001) Flexibilität des Verhandelns - Verhandeln der Flexibilität: Das deutsche und österreichische Tarifsystem im Vergleich. Unpublished manuscript, Max Planck Institute for the Study of Societies, Cologne. HASSEL, ANKE AND BRITTA REHDER. (2001) Institutional Change in the German Wage Bargaining System - The Role of Big Companies. MPIfG Working Paper, 01/9, December. Cologne: Max Planck Institute for the Study of Societies.

Hay, Colin. (2004) Common Trajectories, Variable Paces, Divergent Outcomes? Models of European Capitalism under Conditions of Complex Interdependence. Review of International Political Economy 11 (2): 231-262.

Hiscox, MichaEL. (1999) The Magic Bullet? The RTAA, Institutional Reform, and Trade Liberalization. International Organization 53 (4): 669-698.

HÖPNER, MARTIN. (2007) Coordination and Organization: The Two Dimensions of Nonliberal Capitalism. MPIfG Discussion Paper 07/12. Cologne: Max Planck Institute for the Study of Societies.

IG Metall. (2001) Tarifrunde 2002: Sozialökonomische Rahmenbedingungen in der Metallverarbeitenden Industrie. Frankfurt: IG Metall.

IG Metall. (2002) Daten, Fakten, Informationen. Darmstadt: IG Metall Vorstand. 
IVERSEN, TORBEN. (1996) Power, Flexibility, and the Breakdown of Centralized Wage Bargaining: Denmark and Sweden in Compartive Perspective. Comparative Politics, 28 (4): 399-436.

KAtZenstein, Peter J. (1985) Small States in World Markets: Industrial Policy in Europe. Ithaca: Cornell University Press.

KELlER, BERNDT K., AND ANJA KIRSCH. (2011) Employment Relations in Germany. In International \& Comparative Employment Relations: Globalisation and Change, $5^{\text {th }}$ edition, edited by Greg J. Bamber, Russell D. Lansbury and Nick Wailes. Crows Nest: Allen \& Unwin.

KInG, Desmond, AND DAVID RuedA. (2008) Cheap Labor: The New Politics of "Bread and Roses" in Industrial Democracies. Perspectives on Politics 6 (2): 279-297.

Kohaut, SuZAnNE, AND Claus SchnABEL. (2003) Zur Erosion des Flächentarifvertrags: Ausmaß, Einflussfaktoren und Gegenmaßnahmen. Industrielle Beziehungen 10 (2): 193-219.

KuRdelbusch, ANTJE. (2002) Multinationals and the Rise of Variable Pay in Germany. European Journal of Industrial Relations 8 (3): 325-349.

LONG, J. ScOTT, AND JEREMY FREEZE. (2005) Regression Models for Categorical Outcomes Using Stata (2nd edition). College Station, TX: Stata Press.

MARes, IsABela. (2003) The Politics of Social Risk: Business and Welfare State Development. New York: Cambridge University Press.

MARES, IsABELA. (2006) Taxation, Wage Bargaining, and Unemployment. Cambridge: Cambridge University Press.

Martin, Cathie Jo. (2000) Stuck in Neutral: Business and the Politics of Human Capital Investment Policy. Princeton: Princeton University Press.

Mayda, Anna M., And Dani RodriK. (2005) Why Are Some People (and Countries) More Protectionist than Others? European Economic Review 49 (6): 1393-1430.

Melitz, MARC J. (2003) The Impact of Trade on Intra-Industry Reallocations and Aggregate Industry Productivity. Econometrica 71 (6): 1695-1725.

Milner, Helen V. (1997) Industries, Governments, and the Creation of Regional Trade Blocs. In The Political Economy of Regionalism, edited by Edward D. Mansfield and Helen V. Milner. New York: Columbia University Press. 
RAESS, DAMIAN. (2006) Globalization and why the 'time is ripe' for the transformation of German industrial relations. Review of International Political Economy 13 (3): 449479.

RAESS, DAMIAN, AND BRIAN BurgoON. (2006) The Dogs that Sometimes Bark: Globalization and Works Council Bargaining in Germany. European Journal of Industrial Relations 12 (3): 287-309.

REHDER, BRITTA. (2003) Betriebliche Bündnisse für Arbeit in Deutschland. Mitbestimmung und Flächentarifvertrag im Wandel. Frankfurt am Main: Campus.

RoDRIK, DANI. (1998) Why Do More Open Economies Have Bigger Governments? Journal of Political Economy 106 (5): 997-1032.

RuEDA, DAVID. (2007) Social Democracy Inside Out. Partisanship and Labor Market Policy in Industrialized Democracies. Oxford: Oxford University Press.

RUEDA, DAVID, AND JONAS PONTUSSON. (2000) Wage inequality and varieties of capitalism. World Politics 52 (3): 350-383.

SCHROEDER, WolfGang. (2000) Das Modell Deutschland auf dem Prüfstand: zur Entwicklungen der Industriellen Beziehungen in Ostdeutschland (1990-2000). Wiesbaden: Westdeutscher Verlag.

SCHROEDER, WolfGANG, AND BURKARD RUPPERT. (1996) Austritte aus Arbeitgeberverbänden: Motive - Ursachen - Außmass. WSI Mitteilungen 5: 316-328.

SilviA, StEPHEN J. (1997) German Unification and Emerging Divisions within German Employers Associations: Cause or Catalyst? Comparative Politics 29 (2): 187-208.

Silvia, StePhen J., AND WolfGAng Schroeder. (2007) Why Are German Employers Association Declining? Comparative Political Studies 40 (12): 1433-1459.

SosKICE, DAVID. (1990) Wage Determination: The Changing Role of Institutions in Advanced Industrialized Countries. Oxford Review of Economic Policy 6 (4): 36-61.

StÄDEle, DANIEla, AND DANA MüLleR. (2006) Codebuch zum IAB-Betriebspanel. Version 1: Längsschnitt 1993-2005 (6. Überarbeitete Auflage)(FDZ Datenreport, Nr. 06/2006). Nürnberg: Research Data Centre (FDZ), Federal Employment Service.

Streeck, WolfGang. (1994) Pay Restraint Without Incomes Policy: Institutionalized Monetarism and Industrial Unionism in Germany. In The Return to Incomes Policy, edited by Ronald Dore, Robert Boyer and Zoe Mars. London: Pinter. 
StreecK, Wolfgang. (2001) Tarifautonomie und Politik: Von der Konzertierten Aktion zum Bündniss für Arbeit. In Die deutschen Arbeitsbeziehungen am Anfang des 21. Jahrhunderts: Eine Bestandsaufnahme, edited by Arbeitgeberverbände, Gesamtverband der metallindustriellen Arbeitgeberverbände. Köln: Deutscher Institutsverlag.

Streeck, WolfGang. (2009) Re-Forming Capitalism: Institutional Change in the German Political Economy. Oxford: Oxford University Press.

STREeCK, WolfGAnG, AND BRITTA REHDER. (2003) Der Flächentarifvertrag: Krise, Stabilität und Wandel. Industrielle Beziehungen 10 (3): 341-362.

Swank, DuAnE. (2002) Global Capital, Political Institutions, and Policy Change in Developed Welfare States. Cambridge: Cambridge University Press.

Swenson, Peter, And Jonas Pontusson. (2000) The Swedish Employer Offensive against Centralized Wage Bargaining. In Unions, employers, and central banks: Macroeconomic coordination and institutional change in social market economies, edited by Torben Iversen, Jonas Pontusson and David Soskice. New York: Cambridge University Press.

Thelen, Kathleen. (2000) Why German Employers Cannot Bring Themselves to Dismantle the German Model. In Unions, employers and central banks: Macroeconomic coordination and institutional change in social market economies, edited by Torben Iversen, Jonas Pontusson and David Soskice. New York: Cambridge University Press.

Thelen, Kathleen, And Christa VAn Wijnbergen. (2003) The Paradox of Globalization: Labor Relations in Germany and Beyond. Comparative Political Studies 36 (8): 859-880.

TraXLER, FranZ, AND BERnd BRANDL. (2009) Towards Europeanization of Wage Policy. European Union Politics 10 (2): 177-201.

Turner, Lowell. (1998) Fighting for Partnership: Labor and Politics in Unified Germany. Ithaca: Cornell University Press.

VÖLKL, MARTIN. (1998) Krise des Flächentarifvertrages und Integrationsfähigkeit von Arbeitgeberverbänden. Empirische Untersuchungen am Beispiel zweier 
mittelständischer baden-württembergischer Branchen. Industrielle Beziehungen 5 (2): 165-192.

WAGNER, JOACHIM. (2007) Exports and Productivity: A Survey of the Evidence from Firmlevel Data. The World Economy 30 (1): 60-82.

Wallerstein, Michael. (1990) Centralized Bargaining and Wage Restraint. American Journal of Political Science 34 (4): 982-1004.

WALLERSTEIN, Michael. (1998) The Impact of Economic Integration on European WageSetting Institutions. In Forging an Integrated Europe, edited by Barry Eichengreen and Jeffry Frieden. Ann Arbor: University of Michigan Press.

WeISS, MANFRED, AND MARLENE SCHMIDT. (2000) Labor Law and Industrial Relations in Germany. The Hague: Kluwer Law International.

ZIMMER, STEFAN. (2002) Jenseits von Arbeit und Kapital? Unternehmerverbände und Gewerkschaften im Zeitalter der Globalisierung. Opladen: Leske \& Budrich. 
TABLE 1. Export Dependence and Wage Bargaining in Metalworking

\begin{tabular}{|c|c|c|c|c|}
\hline & $\begin{array}{c}\text { (1) } \\
\text { Bivariate }\end{array}$ & $\begin{array}{c}\text { (2) } \\
\text { Baseline } \\
1\end{array}$ & $\begin{array}{c}\text { (3) } \\
\text { Full }\end{array}$ & $\begin{array}{c}(4) \\
\text { Baseline- } L D V\end{array}$ \\
\hline Exports $\mathrm{Ch}_{\mathrm{t}-2}$ & $\begin{array}{c}0.237 * * * \\
(0.065)\end{array}$ & $\begin{array}{c}0.233^{* * * *} \\
(0.059)\end{array}$ & $\begin{array}{c}0.220 * * * \\
(0.067)\end{array}$ & $\begin{array}{c}0.244 * * * \\
(0.063)\end{array}$ \\
\hline Wage increase $\mathrm{Ch}_{\mathrm{t}-1}$ & & & & $\begin{array}{c}0.102 \\
(0.175)\end{array}$ \\
\hline Productivity Ch & & $\begin{array}{c}0.126 \\
(0.205)\end{array}$ & $\begin{array}{c}0.094 \\
(0.260)\end{array}$ & $\begin{array}{c}0.164 \\
(0.218)\end{array}$ \\
\hline Unemployment $\mathrm{Ch}_{\mathrm{t}-1}$ & & $\begin{array}{c}-0.069 * * \\
(0.026)\end{array}$ & $\begin{array}{l}-0.059 \\
(0.034)\end{array}$ & $\begin{array}{l}-0.061^{*} \\
(0.030)\end{array}$ \\
\hline Economic growth $\mathrm{Ch}$ & & & $\begin{array}{c}0.004 \\
(0.286)\end{array}$ & \\
\hline Employment Ch & & & $\begin{array}{c}0.057 \\
(0.129)\end{array}$ & \\
\hline Constant & $\begin{array}{c}0.908 * * * \\
(0.268)\end{array}$ & $\begin{array}{c}0.794 \\
(0.550)\end{array}$ & $\begin{array}{c}0.891 \\
(0.660)\end{array}$ & $\begin{array}{c}0.541 \\
(0.706)\end{array}$ \\
\hline Observations & 24 & 24 & 24 & 24 \\
\hline R-squared & 0.37 & 0.56 & 0.57 & 0.57 \\
\hline
\end{tabular}

(Notes. Dependent variable: \% annual rate of wage change (real wage increase). OLS coefficients with standard errors (in parentheses). * significant at 10\%; ** significant at 5\%; *** significant at $1 \%$. Variable definition: Exports: \% annual change in sector's export dependence; Productivity: \% annual rate of productivity change in the economy; Unemployment: \% annual change in unemployment rate; Economic growth: \% annual rate of GDP growth; Employment: \% annual change in sector's employment.) 
TABLE 2. Export Dependence and Collective Agreement Coverage in Metalworking

\begin{tabular}{|c|c|c|c|c|}
\hline \multirow[b]{2}{*}{ Exports $\mathrm{Ch}_{\mathrm{t}-2}$} & \multicolumn{4}{|c|}{$1994-2007$} \\
\hline & $\begin{array}{l}-0.293^{*} \\
(0.146)\end{array}$ & $\begin{array}{l}-0.217 \\
(0.223)\end{array}$ & $\begin{array}{c}-0.305^{* *} \\
(0.138)\end{array}$ & $\begin{array}{l}-0.291 \\
(0.220\end{array}$ \\
\hline Coverage $\mathrm{Ch}_{\mathrm{t}-1}$ & & & $\begin{array}{l}-0.370 \\
(0.239)\end{array}$ & $\begin{array}{l}-0.364 \\
(0.259\end{array}$ \\
\hline Wage increase $\mathrm{Ch}$ & & $\begin{array}{l}-0.235 \\
(0.514)\end{array}$ & & $\begin{array}{l}-0.045 \\
(0.511)\end{array}$ \\
\hline Constant & $\begin{array}{l}-0.447 \\
(0.589)\end{array}$ & $\begin{array}{l}-0.399 \\
(0.618)\end{array}$ & $\begin{array}{l}-0.927 \\
(0.637)\end{array}$ & $\begin{array}{l}-0.910 \\
(0.695\end{array}$ \\
\hline Observations & 14 & 14 & 14 & 14 \\
\hline R-squared & 0.25 & 0.27 & 0.39 & 0.39 \\
\hline
\end{tabular}

(Notes. Dependent variable: $\%$ annual change in coverage (West Germany). OLS coefficients with standard errors (in parentheses). * significant at $10 \%$; ** significant at $5 \%$; *** significant at $1 \%$. Variable definition: see Table 1.) 
TABLE 3. Export Dependence and Following Collective Agreements

Export share $_{\mathrm{t}-1}$

Works council

Exports $_{\mathrm{t}-1} *$ Works Council

Size $(1,000)$

Outward FDI $\mathrm{I}_{\mathrm{t}-1}$

Location East Germany

Unskilled prop.

Production workers prop.

Unemployment $_{\mathrm{t}-1}$

Stand-alone firm

New plant

Public ownership

Constant

10 industry dummies

Observations

Log pseudo-likelihood

Pseudo R-squared
(1)

Domesticoriented firms

$-0.547 * * *$

(0.208)

$0.869 * * *$

(0.071)

$0.534 * * *$

(0.137)

0.074

(0.288)

$-0.425 * * *$

(0.101)

$-0.173$

(0.166)

$0.542 * * *$

(0.167)

$-0.116^{*}$

(0.060)

$-0.225 * *$

(0.091)

$-0.385 * * *$

(0.049)

$0.861 * * *$

(0.121)

$-0.053$

(0.220)

Yes

6,652

$-3,628.5$

0.21
(2)

Exporting firms

$-0.058$

(0.230)

$1.031 * * *$

(0.107)

$0.487 * * *$

(0.112)

$0.389 * *$

(0.165)

$-0.150$

(0.108)

$-0.220 *$

(0.122)

$0.308 * * *$

(0.086)

$-0.126$

(0.128)

$-0.365 * * *$

(0.055)

$-0.385 * * *$

(0.068)

$0.545 * * *$

(0.100)

$0.488 * * *$

(0.088)

Yes

3,626

$-1,585.5$

0.28
(3)

Domesticoriented firms

$-0.686 * * *$

(0.204)

$0.814 * * *$

(0.083)

$0.424 * *$

(0.182)

$0.532 * * *$

(0.136)

0.059

(0.294)

$-0.422 * * *$

(0.101)

$-0.176$

(0.166)

$0.539 * * *$

(0.168)

$-0.115 *$

(0.060)

$-0.226 * *$

(0.092)

$-0.385 * * *$

(0.049)

$0.877 * * *$

(0.123)

$-0.034$

(0.222)

Yes

6,652

$-3,625.8$

0.21
(4)

Exporting firms

$-0.697 * *$

(0.352)

$0.856^{* * * *}$

$(0.122)$

$0.930 * *$

(0.364)

$0.453 * * *$

(0.114)

$0.414 * *$

(0.177)

$-0.122$

(0.112)

-0.218 *

(0.121)

$0.292 * * *$

(0.092)

$-0.139$

$(0.128)$

$-0.365 * * *$

(0.055)

$-0.390 * * *$

$(0.067)$

$0.558 * * *$

(0.095)

$0.573 * * *$

(0.101)

Yes

3,626

$-1,575.6$

0.29

(Notes. Dependent variable is binary measure of whether establishment follows an industry- or firm-level collective bargaining agreement (yes $=1 ; n o=0$ ). Threshold domestic- versus export-dependence is foreign sales $=10 \%$. Probit coefficients with robust standard errors (in parentheses), clustered over branch. * significant at $10 \%$; ** significant at $5 \%$; *** significant at $1 \%$.) 
FIG 1. Ten-year Average Wage Increase and Productivity Growth, German Metalworking, 1971-2007

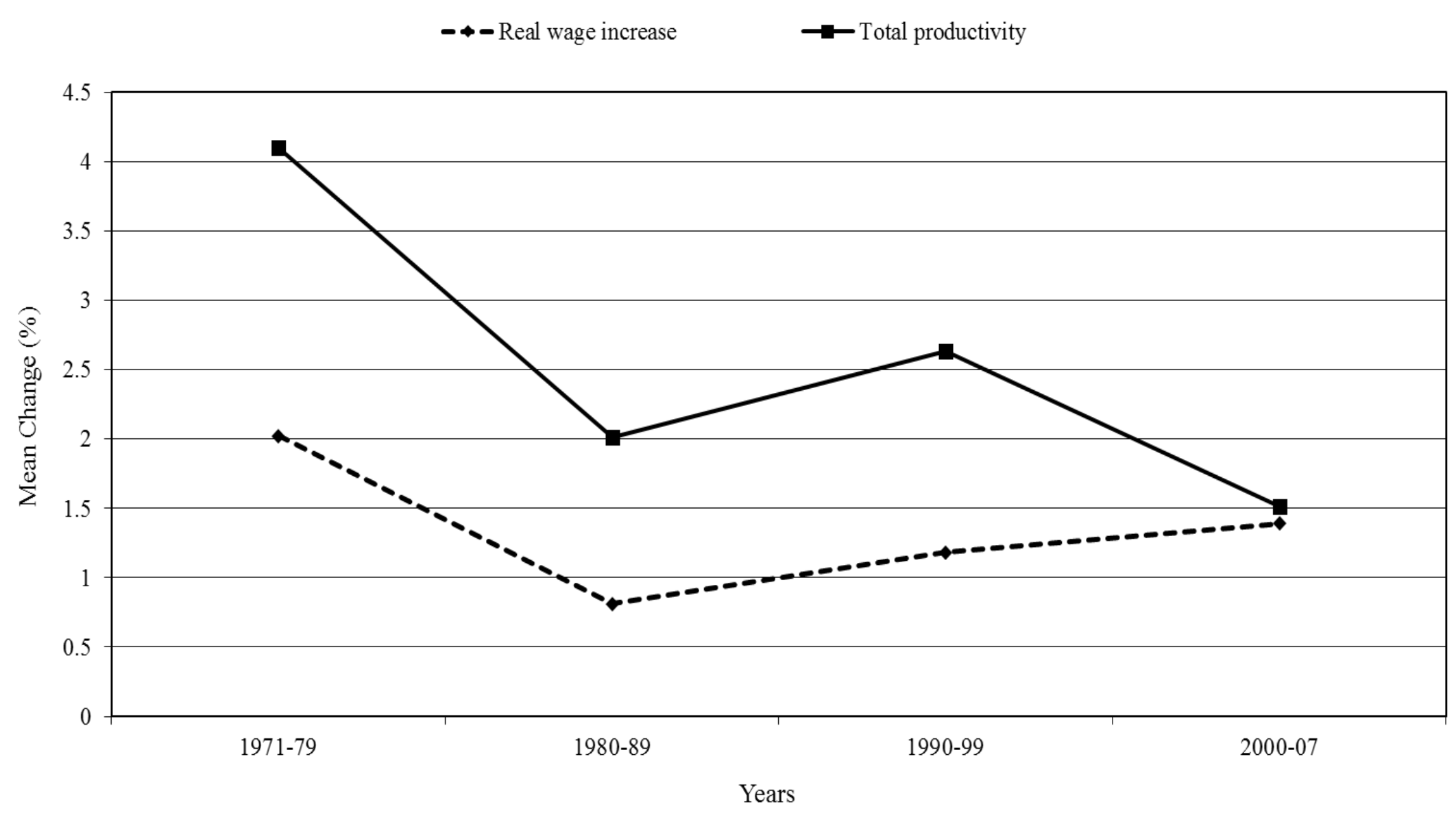


FIG 2. Change in Export Dependence and Wage Increase,

German Metalworking, 1984-2007

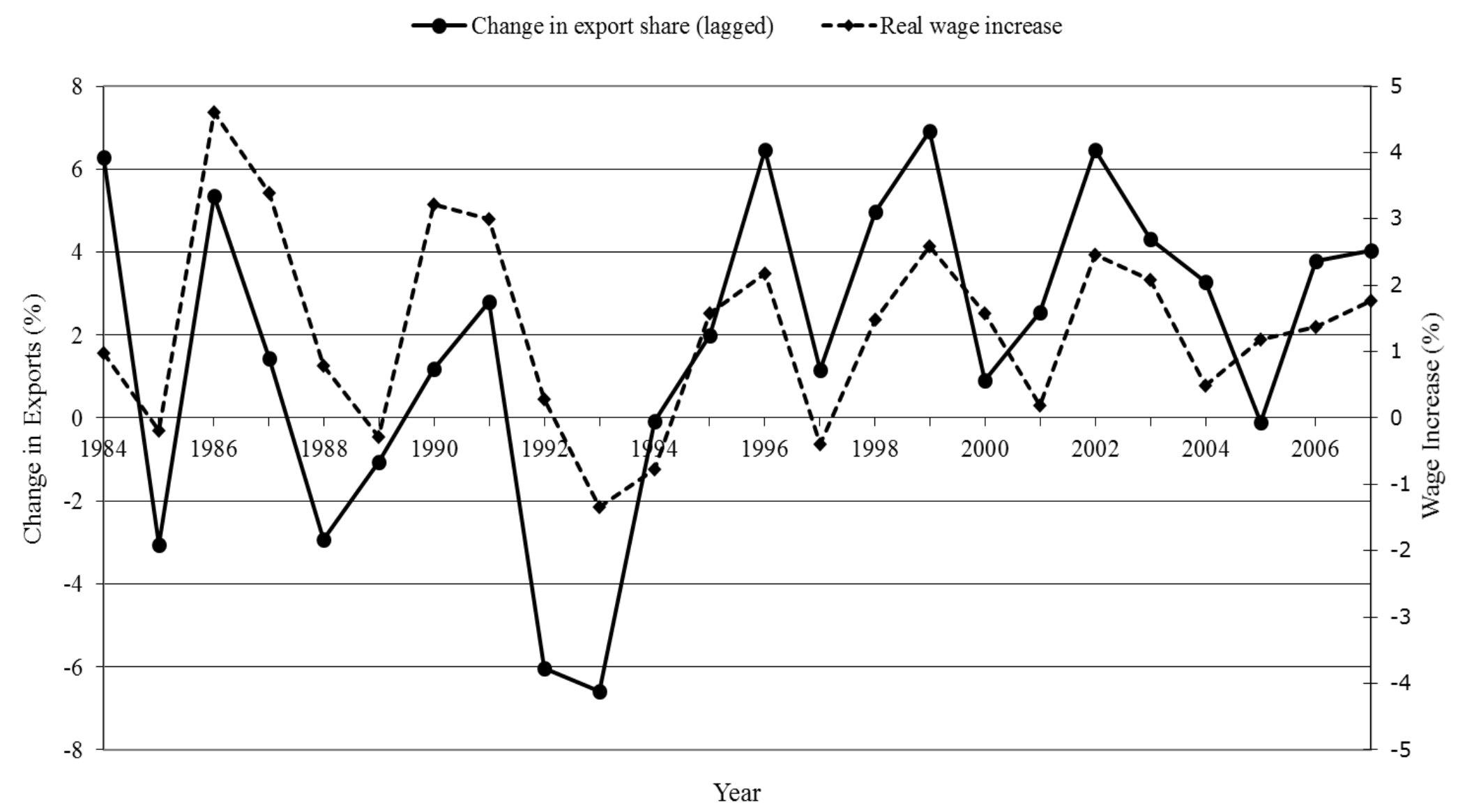


${ }^{1}$ The VofC framework only allows financial globalization to unsettle national institutions mainly because it alters corporate finance (Hall and Soskice 2001:60-2).

${ }^{2}$ Strictly speaking, collective bargaining is regional, but the contract negotiated in the pilot district is extended in its essentials to all other districts. Regional variations are minor and tend not to relate to yearly wage rises (Streeck 1994:120).

${ }^{3}$ Due to convention, organized employers provide identical conditions to union and non-union members.

${ }^{4}$ Collective bargaining in the public sector has long been nationally centralized, but an offensive by employers in search of flexibility decentralized bargaining in 2006, resulting in state employees negotiating separately from federal and municipal employees (Keller and Kirsch 2011). Behrens and Jacoby (2004) document variation in union strategies and flexibility across private sector industries.

${ }^{5}$ We note an evolution in Thelen's thinking about the nature of the cleavage from her earlier emphasis on firm size (Thelen 2000).

${ }^{6}$ Thelen draws on in-depth case analysis of one bargaining round. Silvia and Schroeder's use of real hourly compensation prevents any outright refutation of Thelen's thesis because comparing wage settlements and hourly income is like comparing apples and oranges. We focus on wage settlements because they capture the wage floor in collective agreements, which is the relevant measure if one is interested in whether firms follow collective agreements. Hourly income is an average for the industry.

${ }^{7}$ Quantitative studies have explored the domestic determinants of collective bargaining coverage (Kohaut and Schnabel 2003).

${ }^{8}$ We posit a causal arrow running from exporting to success. An alternative but not mutually exclusive hypothesis points to self-selection of the more productive firms into export markets (Melitz 2003). For an overview of the theory and evidence of the relationship between exports and productivity, see Wagner (2007). We address the possibility of omitted-variable bias by controlling for productivity in robustness checks.

${ }^{9}$ Our account differs from the argument by Swenson and Pontusson (2000) about institutional change in wage bargaining in Sweden in two fundamental ways: (i) the outcomes differ, the decline of industry-wide collective bargaining coverage versus the de-centralization of national-level wage bargaining; and (ii) the domestic-/export-oriented cleavage refers to relations among firms within tradeable sectors (that is, intrasectoral cleavages) versus relations across sectors (that is, inter-sectoral cleavage).

${ }^{10}$ Neither does the data permit testing the hypothesis of a split between suppliers and assemblers.

${ }^{11}$ Data source is Gesamtmetall, Tables 29.1 and 29.2, available at http://www.gesamtmetall.de/gesamtmetall/meonline.nsf/id/DE Zeitreihen. Our data ignores some of the complexity of wage agreements, such as lump sum payments and other gimmicks (for example, 14 month contracts).

${ }^{12}$ Table with annual economic indicators of wage policy over the period 1971-2007 is available upon request.

${ }^{13}$ Our result is consistent with the finding based on hourly compensation data of wage restraint in recent years (Mares 2006; Silvia and Schroeder 2007; Carlin and Soskice 2009). It may even be reconciled with Silvia and Schroeder's (2007) finding that changes in mean hourly wages grew smaller over time: widespread concession bargaining on non-wage issues at the firm level during the years of intensified globalization might well have offset rising costs owing to sectoral wage increases.

${ }^{14}$ We lack comparable data for the 1970s due to a change in industry classification in 1979-1980.

${ }^{15}$ Analysis of material from wage campaigns reveals that whereas the 1992 round took place against the background of the 1992-1993 domestic recession, the 1994 round marked a watershed as employers went into an unprecedented offensive demanding cuts in costs amidst concerns with international competitiveness. ${ }^{16}$ Our choice of variables and time lags follows how IG Metall thinks about the issues (IG Metall 2001). ${ }^{17}$ I thank one anonymous reviewer for emphasizing to me that the social partners also use quarterly data for some economic series. Further study should consider more systematically different lag structures using quarterly and/or annual data.

${ }^{18}$ Own calculations based on Gesamtmetall figures.

${ }^{19}$ Our analysis also assumes that the year in which a firm manager decides to leave employers' association coincides with the year of high settlement. This is not necessarily the case because a firm may leave when the union announces its wage claim at the onset of a bargaining round.

${ }^{20}$ Own calculations based on statistics from the Federal Statistical Office.

${ }^{21}$ To be clear, those complications emanate from the facts that average export sales grew faster than average domestic sales in the recent period and that IG Metall's wage bargaining strategy targeted the economic 
conditions in the profitable exporting firms. Weak internal aggregate demand but booming exports that drive growth characterize the German economy in recent years (Carlin and Soskice 2009; IG Metall 2001:10).

${ }^{22}$ Remote data access via the Research Data Centre (FDZ) of the German Federal Employment Agency (BA) at the Institute for Employment Research (IAB).

${ }^{23}$ Data is from "STAN Database for Industrial Analysis" and "Statistics on International Trade in Services."

${ }^{24}$ Half of German export-oriented manufacturing firms report export-to-production ratios of .15 or lower. And the distribution of firms by export intensity has remained stable over time (see Bernard and Wagner 1997).

${ }^{25}$ Outward FDI, the foreign employment of German multinationals in a sector as a proportion of domestic employment in that sector, is generated using statistics from OECD's "STAN Database for Industrial Analysis" and Deutsche Bundesbank's "Foreign Direct Investment Stock Statistics." Despite the positive bivariate association between FDI and export share (coefficient of correlation=.68), including FDI does on the whole not pose multicollinearity problems (see below).

${ }^{26}$ Regional unemployment figures are from the Federal Employment Agency.

${ }^{27}$ The ten sector dummies are (i) agriculture, hunting, forestry, fishing; (ii) mining, electricity, gas, and water; (iii) manufacturing; (iv) construction; (v) trade and repair; (vi) transportation and communication; (vii) financial intermediation; (viii) industrial services; (ix) other social services; and (x) public administration. Including these does not pose multicollinearity problems with industry-level globalization measures.

${ }^{28}$ Such mediating effect is also apparent among exporting firms (model 4). We don't elaborate on this result because we don't have particular theoretical expectations, and because this model, and this model alone, suffers from multicollinearity (for example, individual VIF score for export share is 5.9). Re-specifying the model without FDI yields a negative and statistically insignificant coefficient for export share whereas all other coefficients remain similar (results available upon request).

${ }^{29}$ As to whether suppliers have left employers' associations, our theory predicts a split among domesticoriented and exporting suppliers. This begs the question why domestic-oriented suppliers wouldn't benefit indirectly from the export success of the assemblers they supply? One reason is that the gains are indirect, in the end it is up to the assembler to decide whether to share or not those gains, and it appears they don't. 